(c) Indian Academy of Sciences

\title{
Erratum
}

\section{Associations of POU1F1 gene polymorphisms and protein structure changes with growth traits and blood metabolites in two Iranian sheep breeds}

Mostafa Sadeghi, Ali Jalil-Sarghale and Mohammed Moradi-Shahrbabak

J. Genet. 93, 831-835

The characters $\bar{D}, \overline{A W}, \overline{B W}$ and $\bar{A}$ (italic $\mathrm{D}, \mathrm{AW}, \mathrm{BW}$ and A with bar above), were misprinted as $D^{\prime}, A W^{\prime}, B W^{\prime}$ and $A^{\prime}$ in equations (i), (ii) and (iii) in the section 'Materials and methods'. All occurrence of $D^{\prime}, A W^{\prime}, B W^{\prime}$ and $A^{\prime}$ should be read as $\bar{D}, \overline{A W}, \overline{B W}$ and $\bar{A}$.

\section{Journal of Genetics Online Resources}

\section{January - March 2015}

Qu X., Cui Y., Yu T., Hu T., Wang C., Lv X. and Ma Y. 2015 Detection of $\alpha_{\mathrm{S} 2}$-casein variants in Chinese yak (Bos grunniens) by PCR-SSCP. J. Genet. 94, e1-e4. Online only: http://www.ias.ac.in/jgenet/OnlineResources/94/e1.pdf

Zhang L., Lu S., Sun D. and Peng J. 2015 Genetic variation and geographical differentiation revealed using ISSR markers in tung tree, Vernicia fordii. J. Genet. 94, e5-e9. Online only: http://www.ias.ac.in/jgenet/OnlineResources/94/e5.pdf

Yu D.-H., Qu N.-N. and Huang G.-J. 2015 Isolation and screening of microsatellite markers from the pearl oyster, Pinctada fucata using FIASCO method. J. Genet. 94, e10-e12. Online only: http://www.ias.ac.in/jgenet/OnlineResources/94/e10.pdf

Barat A., Sahoo P. K., Kumar R., Mir J. I., Ali S., Patiyal R. S. and Singh A. K. 2015 Molecular characterization of rainbow trout, Oncorhynchus mykiss (Walbaum, 1792) stocks in India. J. Genet. 94, e13-e18. Online only: http://www.ias.ac.in/jgenet/OnlineResources/94/e13.pdf

Behere G. T., Firake D. M., Burange P. S., Firake P. D., Azad Thakur N. S. and Ngachan S. V. 2015 Utility of ITS1 as a molecular tool for reliable identification of Henosepilachna pusillanima and H. septima (Coleoptera: Coccinellidae). J. Genet. 94, e19-e23. Online only: http://www.ias.ac.in/jgenet/OnlineResources/94/e19.pdf 